\title{
What Makes a Change Unsuccessful through the Eyes of Teachers
}

\author{
Sabiha Odabasi Cimer ${ }^{1}$ \\ ${ }^{1}$ School of Education, Karadeniz Technical University, Trabzon, Turkey \\ Correspondence: Sabiha Odabasi Cimer, School of Education, Karadeniz Technical University, Trabzon, Turkey. \\ Tel: 90-462-377-7323. E-mail: sabihaodabasi@gmail.com
}

Received: August 11, 2017

doi:10.5539/ies.v11n1p81
Accepted: November 7, $2017 \quad$ Online Published: December 22, 2017

URL: https://doi.org/10.5539/ies.v11n1p81

\begin{abstract}
Over the past two decades, Turkey has initiated a reform movement to change her classroom assessment system to accommodate performance-based alternative assessment methods in schools. However, research investigating the impact of assessment reform on learning and teaching in schools report that performance assessment approaches have not been implemented effectively. This study investigated the teacher related factors behind the adoption decisions of teachers of these changes introduced. Data for the study were collected through interviews with 53 biology teachers in 24 schools. According to the findings, teachers' lack of self-agency, superficial understanding of the ideas introduced, mistrust that the innovations will work in practice, skepticism about the need for a change and inadequate knowledge and abilities as a result of ineffective dissemination and professional guidance were the main factors affecting the success of the reform. Suggestions to overcome barriers to reform and implications of the findings in managing change are presented and discussed at the end of the paper.
\end{abstract}

Keywords: assessment reform, educational change, teacher views

\section{Introduction}

Recently, education systems worldwide have been increasingly focusing on the effective implementation of performance assessments in schools (Assessment Reform Group [ARG], 2002; Black \& Wiliam, 1998; Bol, Nunnery, Stephenson \& Mogge, 2000; Ross, Hannay \& Hogaboam-Gray, 2000; Scouller, 1996; Stiggins, 2000; Stiggins \& Conklin, 1992). This growing interest in performance assessment is due to an emerging awareness that it increases student learning and achievement (Black \& Wiliam, 1998; Borko, Flory \& Cumbo, 1993; Gardner 2006; McMillan, 2007). Based on the research evidence showing that performance assessment indeed provides the means for improving student learning, the rationale, purpose, and format of assessment in schools in Turkey have also been questioned and reviewed as part of the efforts to reform education for the last two decades. Performance assessment approaches which are based on the constructivist view of teaching and learning have been introduced by the Ministry of National Education and the curriculum programs and textbooks for both primary and secondary schools have been re-written according to the requirements of the new system.

Since then, a number of studies have been conducted to investigate the effects of the reforms or whether performance assessment approaches had been implemented in the classrooms (Ayas et al., 2007; Cimer, Cakir, \& Cimer, 2010; Demir, Ozturk, \& Dokme, 2011; Metin \& Ozmen, 2010; Yasar, Gultekin, Turkan, \& Yildiz, 2005). Nevertheless, they all report that the changes introduced have not been implemented in schools effectively. The factors identified in the literature as affecting the implementation of the changes were the university entrance exam which is a high stakes test, inadequate facilities in schools, low quality of students, ineffective in-service training etc.

It is true that change cannot be successfully implemented simply by the production of policy documents and curriculum standards. Research has shown that the teacher is the key factor in any reform in education (Armstrong, 2008; Goh, 1999; Harris, 2005; Morrison, 2010; Riley \& Louis, 2000; Sarason, 1996 ). Teachers' knowledge and perceptions of change serve as critical factors that impact their decisions about implementing (Putnam \& Borko, 1996). As Goh (1999) indicates, successful implementation of any innovation or change lies in the hands of teachers because 'at the end of the day, it is these teachers who will determine whether innovations will eventually be carried out inside the classroom' (p. 18). Fullan and Hargreaves (1996) also argue that there is a "need to first focus on how teachers make sense of the mandates and policies because there will be 
no educational reform until after teachers interpret the policies and make decisions based on their beliefs about the new demands" (p. 12).

It is well-accepted fact that change is not always accepted easily and experienced teachers are often criticized for being resistant to change (Fullan \& Hargreaves, 1996). Many reasons were listed in the literature for such resistance (Evans, 1996; Fullan, 1991; Fullan \& Hargreaves, 1996). One is that teachers feel that they are left out and do not feel ownership of the ideas imposed. They generally are not given chance to provide input when policies are constructed even though they are the individuals who are expected to implement changes. Another reason is that reforms challenge teachers' old views of teaching, learning, and assessment. Some teachers worry that the innovation will not work or will make the matters worse (Fullan \& Hargreaves, 1992, p. 5). Fullan (1991) indicates that the failure of many reform movements has been attributed to the neglect by reformers of teachers' perceptions. Thus, teachers' role is critical to the success of reforms. In other words, without support and commitment from teachers, there will be little or no chance for any reform effort to succeed. Especially when reforms are top-down as those in Turkey, the role of the teacher becomes more important because s/he is the final agent who determines whether these top-down initiatives will enter the classrooms. In fact, if a proposed change is recognized by teachers as addressing an important need, then it is more likely to be implemented (Ayas et al., 2007; Fullan, 1991). Thus, the change of teaching practice relies on the change of teachers' knowledge and perceptions. Hence, teachers' perceptions of reform or change are important to determine if they exert commitment or adapt their practice accordingly.

All these insights suggest that in order to understand the role of teachers in reforms, their knowledge, attitudes, and beliefs should be analyzed first. Such empirical evidence provided by the implementers of the reform may offer lessons for those who plan reforms and pave the way for professional development initiatives. Specifically, this paper aims to explore teachers' perceptions that shape their decisions to adopt changes. For this purpose, the paper draws on data gathered through 53 in-depth interviews of secondary school Biology teachers. The results of the research will help policymakers and educational leaders to better understand the perspectives of the teachers. If teachers' perspectives are known and understood, they will have the knowledge to provide support and plan for future changes by implementing any suggestions or outcomes introduced through this study.

\section{Method}

\subsection{The Sample}

The study was conducted with 53 Biology teachers working in 24 secondary schools. They ranged in years of teaching experience from five to twenty-six years. The scope and focus of this study were delimited to include only teachers, rather than all stakeholders (e.g., students, administrators, parents) involved in the change.

\subsection{Data Collection}

This study employed the survey method using semi-structured interviews as the data collection tools to reveal teachers' views on the factors that impede effective implementation of reforms in assessment. The semi-structured interview was chosen as the data collection tool in this study in order to leave areas where the conversation could lead in different directions or more in-depth with each person. This inquiry is a qualitative phenomenological study that reveals the perceptions of 53 teachers in 24 schools.

The interview questions asked teachers about their knowledge and use of performance assessment methods. Since the interviews allowed for conversation between the teachers and the researcher, the interviews were audio recorded and later transcribed into Word document.

\subsection{Data Analysis}

The data from the interviews were analyzed qualitatively following the procedures advised by Merriam (1988), Bogdan and Biklen (1992) and Miles and Huberman (1994). After completing the data collection, tape recordings were transcribed verbatim as soon as possible. Word-processed transcripts were taken back to the participants and they were asked if they wanted any changes in the text. This aimed to increase the accurateness of the transcripts, in other words, contribute to the reliability of the data, engender trust and confidence in the researcher and provide the informants with a sense of contribution (Miles \& Huberman, 1994). However, none of the participants made any changes. However, Afterwards, content analysis - which comprised generally determining codes first; then, pulling them together to form categories based on the research questions, so that they became the answers to the research questions - was carried out. Because of ethical considerations, when analyzing the data every teacher was assigned an identifier number; for example, T1 stands for 'Teacher 1'. 


\section{Results and Discussion}

The data obtained from the interviews showed that the changes introduced through the new assessment reform had not been implemented effectively in practice. Different reasons could be identified from the data. These reasons are presented and discussed in this section based on the interview data.

\subsection{Superficial Understanding of the Innovation}

As indicated earlier, the idea brought by the reform should present an innovation to teachers (Fullan, 1991). The results of the current study showed that this was an obvious issue for the study's teachers. Interestingly enough, all of the teachers indicated that the ideas brought by the reform were not innovative. In other words, performance assessment in terms of conducting oral exams, assigning projects and assignments was not new to them as they had already been using them. Thus, they did not seem to understand what to change. A common view was:

I have already been doing oral exams and looking at their (students) in class performance. I assign research tasks. I have not changed anything in my practice. They (policymakers) do not ask anything really different from what I already do ...(T5)

Clearly, the concept of performance assessment has not really been understood by the study's teachers. As they did not realize that the proposed reform indeed introduces new concepts and requirements, they downgrade its value thinking that they had already been doing it. Thus, the requirements of the reform have not been implemented.

However, there were teachers who reported making some changes in their practices as a result of the reform. Eleven of the teachers indicated that they started using 'branched three', 'structured grid' and 'word association' methods as the performance assessment methods. All of these teachers were those who had experience of 5-10 years. They indicated that these were the methods taught during the in-service courses that they had attended or their preservice education. Surprisingly, indeed, these three methods were the only methods mentioned by all of the teachers who indicated that they had attended in-service courses on the new assessment system. Thus, obviously, the teachers limited the performance assessment to use of "branched three", "structured grid" and "word association" methods, which do not present essential characteristics of performance assessment concept.

Looking at the contents of the in-service programs conducted by the Ministry of National Education, it can be seen that these are the only methods of assessment covered. These methods indeed are different forms of tests rather than being performance assessment methods. Hence, clearly, not only the teachers but also the policymakers misinterpret what performance assessment is. What seems to be wrong is that we try to construct a building without a foundation.

The new assessment system requires teachers to set tasks that assess students' higher-order thinking skills and use clear criteria and rubrics to evaluate the results. None of the teachers in the study mentioned using rubrics. Only one of the teachers indicated using portfolio in his biology classes. He indicated that he had not attended any in-service courses or seminars on the new assessment system; however, he learned about the requirements of the system from the official documents that had been sent to the school by the Ministry of National Education and from his own efforts. Upon examining the portfolios that his students had prepared, it can be said that they were nothing more than a collection of the student selected items in a folder. This indeed was not surprising, since the teacher did not have any training on how to use portfolios.

There are certain elements that make a portfolio portfolio (Cimer, 2011). One is the self-reflection. Students need to write reflective comments on each piece of work that they included in the portfolio and on the whole learning process. Another element is continuous feedback and guidance. Portfolios should be periodically collected by the teachers and returned with feedback. The other element is using rubrics to evaluate the portfolio process. The evaluation criteria should be known by the students from the beginning of the process. There are certainly other things to be considered when implementing portfolios, which have not been included here, such as the quality of work assigned during the process. Hence, the portfolio is not a mere collection of work in a folder and, if used properly, it can increase students' learning (Cimer, 2011).

Thus, the concepts introduced through the assessment reform are not adequately understood and implemented by the study's teachers. It is self-evident that one cannot implement what one do not know. In addition, as indicated earlier, unless teachers accept changing their practice, there is no chance for reforms to succeed. Hence, change starts with teachers' understanding and acceptance of the requirements. This is followed by the commitment. To achieve this, it is vital to convince teachers that the requirements of the change are necessary and feasible (Gunstone \& Northfield, 1988). Literature presents convincing evidence that performance assessment if 
implemented properly, has a potential to enhance and increase students' learning (Black \& Wiliam, 1998). Teachers should be convinced by this evidence, or warrant, before the implementation.

\subsection{The Warrant Is Not Convincing Enough Considering the Context}

The interview data revealed that there was distrust among the study's teachers regarding the benefits of the new assessment approach. Thus, they felt skepticism about the need for a change. During the interviews, although most of the teachers initially expressed positive feelings about the performance assessment approach, when they asked further about the reasons for their ideas, they all confessed that it was not "that helpful" to students in our "examination based" system.

The effects of high stakes tests on instructional and assessment practices in schools have been widely reported by many researchers from different contexts (for example, Black \& Wiliam, 2003; A. Cimer, 2004; S. O. Cimer, 2004; Coombe \& Hubley, 2003; Shepard, 1990; Shepard \& Dougherty, 1991; Smith \& Rothenberg, 1991; ). These studies point out a "backwash effect" from external high stakes tests, that is, tests control curriculum, teaching and learning processes in the classroom. Teachers think that they should adjust their teaching according to the requirements of the tests to increase their students' chances to achieve success and the students only study and learn what they need to know for the test (Black \& Wiliam, 2003; Coombe \& Hubley, 2003).

This study is not an exception. During the interviews, the teachers did acknowledge a constant preoccupation with readying students for the university entrance examination. Below conversation between me, as the researcher, and the participant teachers reflects the common view:

Researcher: You know that performance assessment requires students "do" something, such as conduct research or an experiment. Do you assess your students using these methods?

Teacher14: There is university entrance examination and it is a multiple choice test. They do not assess students' ability to conduct research or do something.

Teacher 2: The students want to take tests instead of doing research or experiment. In the end, they will be assessed through a test.

Such comments were frequently mentioned throughout the interviews. Obviously, competition for university places determined by points obtained in the university entrance examination exerts a powerful backwash effect on the culture of assessment in schools and thereby, on the reforms in assessment.

\subsection{Ineffective Dissemination and Professional Guidance}

Effective dissemination may solve most of the problems on the road to the successful implementation of reforms. In Turkey, as evidenced from the interviews in this study, ineffective dissemination policy was the main reason for the failure of the recent assessment reform. First of all, training of the teachers started after the implementation process. Although this study was conducted about two decades after the reform had been introduced, 29 out of 53 teachers reported that they had not been given any training or seminars on the new assessment system.

Actually, 12 of these 29 teachers indicated that they had attended courses on the curriculum reform in general, which was supposed to introduce the new assessment system, had not included anything about it. In Turkey, the curriculum and assessment reforms have been introduced concurrently. Thus, teachers have been expected to implement both constructivist teaching and performance assessment. The in-service training and seminars conducted to disseminate these reform initiatives were supposed to cover both topics. However, as the teachers indicated, the courses they had attended only covered constructivist teaching and the introduction of the new curricula but there was nothing about the topic of performance assessment. One teacher said; "The training supposed to be on the new curriculum and assessment, but there was nothing about assessment. They just presented what student centered teaching was and, that was it" (T16).

Therefore, teachers without knowing what and how they would do were expected to do. They had the textbooks prepared by the Ministry of National Education and the official forms to be filled in, but they did not have the knowledge of how to implement the new system. One of the teachers said, "What I know is to follow what is in the textbook. The book says 'students do this and students do that' and I assign those tasks. But, there are many different forms to be filled in about different aspects of students' learning. I just fill them in..." (T3).

Another complained about the problems she faced with assigning quality projects and their evaluation; " What is a good project and how will I mark them? They say rubrics should be used, but I do not know what a rubric is and how to use it. I did not have any training on them" (T36).

The teachers who indicated that they had attended a training or a seminar on the new assessment system 
indicated that the courses they had attended actually covered the introduction of both the curriculum and assessment system. They all agreed that only the methods of "branched three", "structured grid" and "word association" were introduced as the performance assessment methods.

In addition to the shallow course content, deskilled course instructors was another concern for the most of the study's teachers. None of the teachers who had attended to the in-service courses on the new assessment system was happy with the quality of the training they had been given. None of the teachers talked positively about the course instructors' knowledge of the new assessment system. One said; "he was supposed to teach us the new assessment approach but he did not know about it either" (T12).

In addition, theoretical presentation without any practical work and limited time were other issues raised by the teachers regarding the quality of the training. These findings regarding the quality of the training were also reported earlier in other studies researching into the effectiveness of in-service courses on the new curriculum and assessment (Ayas et al., 2007; Cimer et al., 2010). Researching into the effectiveness of in-service courses for teachers on the new curriculum and assessment reforms in Turkey, Ayas et al. (2007) report that "current in-service courses are criticized that they are too theoretical and does not involve practical element, and more importantly the course instructors are not expert in their subject. Therefore, current in-service courses were not found effective by the most of the teachers."

Consequently, regardless of attending any courses or seminars, none of the study's teachers actually understood what performance assessment was and how it could improve student learning. They were just applying what they, themselves, picked from the textbook and other official forms.

\subsection{Lack of Self-agency and Ownership}

Teachers, school leaders as well as peer pressure, professional learning, government policy, research findings and public opinion may all be change agents. Especially, teachers as the implementers of change are important change agents in education. Their understanding, acceptance, and commitment determine whether a change or innovation will enter the classrooms since "teachers can always shut the door and get on with what they want to do anyway" (Fullan \& Hargreaves, 1996, p. 14).

The lack of self-agency was obvious in this study's teachers. The self-agency is related to self-motivation and commitment to improve or change practice. Gardner et al. (2008) define "self-agency" as a "powerful device in fostering change because it draws on self-motivation" (p. 8). They claim that without teacher commitment through the self-agency, successful dissemination or professional learning will not be effective. Hence, if it is absent, there is a risk of teachers to downgrade the value of the proposed changes and minimal engagement in practice (ARG, 2008). On the other hand, it is necessary to develop a sense of ownership of the process of change, thereby its implementation sustainability.

These claims are validated by the findings of this study. All of the teachers defined student self-assessment forms as a "useless paperwork" which they do as the Ministry of National Education asked them to. One of the teachers said; "there are lots of paperwork which are no use for pupils. But we have to do them. As the Ministry asks, we have to". During the interviews, comments like "they (the policy makers) never ask for teachers' opinion" were repeated frequently.

Clearly, the teachers implement ideas as the authorities demand them. Therefore, they do not feel ownership of the process nor do they demonstrate self-agency. In order to develop self-agency and the feel of ownership in teachers, there needs to be an external support such as well-organized and delivered professional development programs and they should be involved in the process of formulating changes. Teachers, indeed, may be more knowledgeable about the real problems in schools and the things to be done to solve them than the education authorities (Armstrong, 2008). Teachers' input can beat the odds of reform failure and be extremely valuable to shape teaching and learning in the classroom. Thus, attitudes of either resisting or welcoming change seem to be a question of ownership (Niemi, 2002).

\section{Conclusions and Suggestions}

It is well-known that teachers play a crucial role in the efforts to implement educational change. This study aimed to analyze and review recent reform initiative in classroom assessment in Turkey to reveal teacher-related factors that impede reform efforts in the light of the teachers' views.

Obviously, as the data have shown, the recent reform movement has not been a success in Turkey. Based on the views of the teachers, the study revealed the factors that impede assessment reform being implemented effectively. These factors as the barriers in front of the reform can be summarized under two headings; one is teachers' resistance to change and the other is superficial understanding of the requirements of the change. 
Teachers' resistance to change was mainly due to the lack of self-agency and ownership of the innovation as a result of "top-down" changes mandated by the authorities.

Resistance is a normal reaction to change as it demands new learning, causes anxiety and confusion (Fullan, 1991). It is true that change challenges teachers' acceptance of, and comfort with the status quo. Therefore, implementation of change cannot be possible without convincing teachers that it is essential (Evans, 1996). The self-agency requires two factors to work. One is convincing teachers that the ideas will work in practice and the other is providing well organized professional support. As indicated above, the teachers in this study neither had the theoretical background to implement performance assessment in their classrooms nor did they believe that it would work in practice. Thus, they were not committed to implementing changes.

Hence, as a starting step, a conceptual change in teachers seems essential to make the new concept appear necessary and feasible, so that teachers believe in the benefits of the reform requirements and become willing to implement them (Gunstone \& Northfield, 1988).

To achieve this, teachers need to be supported to overcome difficulties they experience during the implementation of the requirements of the change. Recent research showed that formulating professional learning communities could be a solution to achieve this (e.g. Priestley, Miller, Barrett, \& Wallace, 2010; Wiliam, 2012). The teachers especially reported problems with using the new assessment methods although they indicated that they had attended to in-service courses on the new system. Thus, obviously in-service programs should be prepared adequately and presented by experts.

In addition, teachers tend to resist "top-down" changes mandated by the authorities. In such systems, they implement new methods or ideas because the authorities or curriculum demand them. As Fullan (1991) indicated these changes tend to be superficial and do not last long. However, if teachers are involved in the process of formulating changes, they may be positively willing to change (Hackman \& Johnson, 2004). Thus, attitudes of either resisting or welcoming change are a question of ownership and teachers are more likely to implement changes if they feel ownership of the process (Niemi, 2002). In addition, teachers may know more about the real problems in schools and what could be done to solve them than the education authorities (Armstrong, 2008). Hence, teachers' input can beat the odds of reform failure and be extremely valuable to shape teaching in the classroom and student learning.

Superficiality is determined as another issue in front of the reform. The teachers call what they do 'performance assessment' without realizing that they do not actually do it. Hence, they do not know what they do not know. It was obvious from the data that neither the teachers nor, as the previous research has shown (Ayas et al 2007; Cimer et al., 2010), the reform planners and appraisers had understood the theoretical foundations of the assessment change. Clearly, lack of well-articulated and planned professional development opportunities and dissemination resulted in a superficial understanding of the reform requirements by the teachers.

It is true that success of any reform effort depends on teachers' understanding, acceptance and application of the reform requirements. When asked if they had attended any in-service courses, more than half of the teachers in this study indicated that they had not had any training on the requirements of the new assessment system. However, they did indicate that they tried to do things with what could be learned through their own efforts, namely from textbooks and with the help from colleagues. Obviously, the teachers are struggling with the meaning of change to themselves and their students and the implications it has on their lives. Knowing this, one should not be surprised that the new system has not entered into the classrooms yet. Without training teachers or making them aware of the requirements of the reform how can we expect success? Thus, changes only on paper do not mean that they are implemented in practice.

\section{References}

ARG (Assessment Reform Group). (2002). Testing, motivation, and learning. Cambridge, England: University of Cambridge Faculty of Education.

Armstrong, P. A. (2008). What teachers expect in reform: Making their voices heard. Rowman \& Littlefield Education.

Ayas, A. P., Akdeniz, A., Çepni, S., Baki, A., Cimer A., \& Cimer, S. (2007). Hizmetiçi Egitimin Etkililigi Temel Arastırması (BEP2/04-CQ) Sonuç Raporu, Milli Egitim Bakanlıgl, Projeler Koordinasyon Merkezi Baskanligl Temel Egitim Projesi.

Black, P., \& Wiliam, D. (1998). Assessment and classroom learning. Assessment in Education: Principles, Policy and Practice, 5(1), 7-74. https://doi.org/10.1080/0969595980050102 
Black, P., \& Wiliam, D. (2003). In Praise of Educational Research: Formative Assessment. British Educational Research Journal, 29(5), 623-637. https://doi.org/10.1080/0141192032000133721

Bogdan, R., \& Biklen, S. (1992). Qualitative research for education: An introduction to theory and methods. Boston, Allyn and Bacon.

Bol, L., Nunnery, J., Stephenson, P., \& Mogge, K. (2000). Changes in teachers' assessment practices in the new American schools restructuring models. Teaching and Change, 7(2), 127-146.

Borko, H., Flory, M., \& Cumbo, K. (1993). Teachers' Ideas and Practices About Assessment and Instruction. A Case Study of the Effects of Alternative Assessment in Instruction, Student Learning, and Accountability Practice. CSE Technical Report 366. Los Angeles: Center for Research on Evaluation, Standards, and Student Testing (CRESST).

Cimer, A. (2004). A study of Turkish biology teachers' and students' views of effective teaching for improving teaching in schools and teacher education (Unpublished EdD thesis), The University of Nottingham, School of Education, England.

Cimer, S. O. (2004). An investigation into biology teachers' perceptions of classroom assessment in secondary schools in Turkey (Unpublished EdD thesis). The University of Nottingham, School of Education, England.

Cimer, S. O. (2011). The effect of portfolios on students' learning: Student teachers' views. European Journal of Teacher Education, 34(2), 161-176. https://doi.org/10.1080/02619768.2011.552183

Cimer, S. O., Cakir, I., \& Cimer A. (2010). Teachers' views on the effectiveness of in-service courses on the new curriculum in Turkey, European Journal of Teacher Education, 33(1), 31-41. https://doi.org/10.1080/02619760903506689

Coombe, C. A., \& Hubley, N. (Eds.). (2003). Assessment practices (Case Studies in TESOL Practice Series). Alexandria, VA: Teachers of English to Speakers of Other Languages, Inc. (TESOL).

Demir, R., Ozturk, N., \& Dokme, I. (2011). The views of the teachers taking in-service training about alternative measurement and evaluation techniques: The sample of primary school teachers. Procedia - Social and Behavioral Sciences, 15, 2347-2352. https://doi.org/10.1016/j.sbspro.2011.04.105

Evans, R. (1996). The human side of school change. Reform, resistance, and the real-life problems of innovation. San Francisco, Jossey-Bass Publishers.

Fullan, M. (1991). The new meaning of educational change. London, Cassell.

Fullan, M., \& Hargreaves A. (Eds.) (1992). Understanding teacher development. London, Cassell.

Fullan, M., \& Hargreaves, A. (1996). What's worth fighting for in your school? New York, Teachers College Press.

Gardner, J. (2006). Assessment and learning. London, Sage.

Gardner, J., Harlen, W., Hayward, L., \& Stobart, G. (2008). Changing assessment practice: Process, principles and standards. London, Assessment Reform Group.

Goh, C. (1999). Nationwide curriculum innovation: How do we manage change? In C. Kennedy, P. Doyle, \& C. Goh (Eds.), Exploring change in English language teaching (pp. 5-18), Oxford: Macmillan Heinemann.

Gunstone, R. F., \& Northfield, J. R. (1988). In-service Education: Some constructivist perspectives and examples. Paper presented at The Annual Meeting of the American Educational Research Association, New Orleans, Louisiana. Retrieved from https://eric.ed.gov/?id=ED292787

Hackman, M. Z., \& Johnson, C. E. (2004). Leadership: A communication perspective (4th ed.). Illinois, Waveland press, Inc.

Hadley, G. S. (1999). Innovative curricula in tertiary ELT: A Japanese case study. ELT Journal, 53(2), 92-99. https://doi.org/10.1093/elt/53.2.92

Harris, A., (2005). Teacher Leadership: More than a feel good factor? Journal of Leadership and Policy in Schools, 4(3), 201-209. https://doi.org/10.1080/15700760500244777

McMillan, J. H. (2007). Formative classroom assessment: Research, theory and practice. New York Teacher's College Press.

Merriam, S. B. (1988). Case study research in education. San Francisco, Jossey-Bass.

Metin, M., \& Ozmen, H. (2010). Determination of science and technology teachers' in-service education (inset) 
needs on performance assessment. Kastamonu Education Journal, 18(3), 819-838.

Miles, M. B., \& Huberman, M. (1994). Qualitative data analysis: An expanded sourcebook. Thousand Oaks, Sage.

Morrison, K. (2010). Complexity theory, school leadership and management: Questions for theory and practice. Educational Management Administration and Leadership, 38(3), 374-393. https://doi.org/10.1177/1741143209359711

Niemi, H. (2002). Active learning-a cultural change needed in teacher education and schools. Teaching and Teacher Education, 18(7), 763-780. https://doi.org/10.1016/S0742-015X(02)00042-2.

Priestley, M. Miller, K. Barrett, L., \& Wallace, C. (2010). Teacher learning communities and educational change in Scotland: the highland experience, British Educational Research Journal, 37(2), 265-284. https://doi.org/10.1080/01411920903540698

Putnam, R., \& Borko, H. (1996). Learning to teach. In D. Berliner, \& R. Calfee (Eds.), Handbook of educational psychology (pp. 673-708), New York, Macmillian.

Richards, J. (2002). Why teachers resist change (and what principals can do about it). Principal, 81(4), 75-77.

Riley, K., \& Louis, K. S. (2000). Leadership for change and school reform: International perspectives. London, Routledge Falmer. https://doi.org/10.4324/9780203465882

Ross, J. A., Hannay, L., \& Hogaboam-Gray, A. (2000). Teacher perceptions of the impact of secondary school reform on student assessment in an Ontario high school. A Series of Brief Reports. Retrieved from http://legacy.oise.utoronto.ca/research/field-centres/TVC/RossReports/vol6no4.htm\#_ftn1

Sarason, S. (1996). Revisiting the culture of the school and the problem of change. New York, Teachers College Press.

Scouller, K. (1996). Influence of assessment method on students? Learning approaches, perceptions and preferences: The assignment essay versus the short answer examination. Paper presented at the HERDSA Conference on Different Approaches: Theory and Practice in Higher Education, Perth, Western Australia. Retrieved from http://www.herdsa.org.au/confs/1996/scouller.html

Shepard L. A., \& Dougherty K. C. (1991). Effects of high-stakes testing on instruction. Paper presented at Annual Meetings of the American Educational Research Association and The National Council on Measurement in Education. Retrieved from http://files.eric.ed.gov/fulltext/ED337468.pdf

Shepard, L. A. (1990). Inflated test score gains: Is the problem old norms or teaching the test? Educational Measurement: Issues and Practice, 9(3), 15-22. https://doi.org/10.1111/j.1745-3992.1990.tb00374.x

Smith, M. L., \& Rottenberg, C. (1991). Unintended Consequences of External Testing in Elementary Schools. $\begin{array}{lllll}\text { Educational Measurement: Issues and } & \text { Practice, } & \text { 10(4), } & \text { 7-11. }\end{array}$ https://doi.org/10.1111/j.1745-3992.1991.tb00210.x

Stiggins, R. (2000). Student-involved classroom assessment (3rd ed.). Upper Saddle River, NJ: Prentice-Hall.

Stiggins, R. J., \& Conklin, N. (1992). In teachers' hands: Investigating the practices of classroom assessment. State University of New York press.

Wiliam, D. (2012). Sustaining formative assessment with teacher learning communities. Retrieved from http://www.dylanwiliamcenter.com/files/pdf/Sustaining-TLCs-20140829.pdf?aliId=89372614

Yasar, S., Gultekin, M., Turkan, B., \& Yildiz, N. (2005). Yeni ilkogretim programlarının uygulanmasına ilişsin sinıf ögrretmenlerinin hazır bulunuşluk düzeylerinin ve eğitim gereksinimlerinin belirlenmesi. Paper presented at Erciyes Üniversitesi Sabancı Kültür Sitesi Yeni İlköğretim Programlarını Değerlendirme Sempozyumu, Kayseri.

\section{Copyrights}

Copyright for this article is retained by the author(s), with first publication rights granted to the journal.

This is an open-access article distributed under the terms and conditions of the Creative Commons Attribution license (http://creativecommons.org/licenses/by/4.0/). 